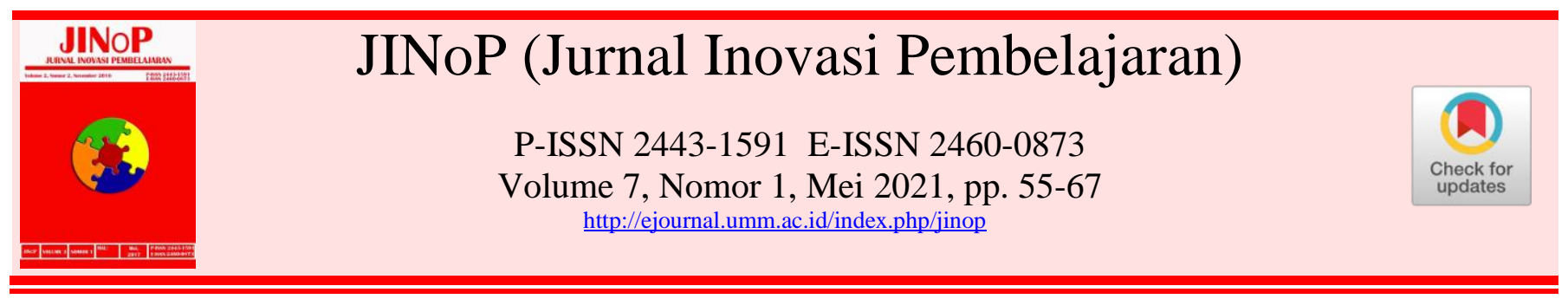

\title{
Gim edukasi berbasis android sebagai optimasi pembelajaran daring di masa pandemi Covid 19
}

\author{
Fitria Nur Hasanah ${ }^{1)^{*}}$, Cindy Taurusta ${ }^{2)}$, Rahmania Sri Untari ${ }^{3)}$, Dini Nurul \\ Hidayah $^{4)}$, Rindiani ${ }^{5)}$ \\ ${ }^{1}$ Pendidikan Teknologi Informasi, Fakultas Psikologi dan Ilmu Pendidikan, Universitas \\ Muhammadiyah Sidoarjo, Jalan Majapahit 666B, Sidoarjo, Indonesia \\ ${ }^{2}$ Pendidikan Teknologi Informasi, Fakultas Psikologi dan Ilmu Pendidikan, Universitas \\ Muhammadiyah Sidoarjo, Jalan Majapahit 666B, Sidoarjo, Indonesia \\ ${ }^{3}$ Pendidikan Teknologi Informasi, Fakultas Psikologi dan Ilmu Pendidikan, Universitas \\ Muhammadiyah Sidoarjo, Jalan Majapahit 666B, Sidoarjo, Indonesia \\ ${ }^{4}$ Teknik Informatika, Fakultas Teknik, Universitas Muhammadiyah Sidoarjo, Jalan Majapahit 666B, \\ Sidoarjo, Indonesia \\ ${ }^{5}$ Pendidikan Teknologi Informasi, Fakultas Psikologi dan Ilmu Pendidikan, Universitas \\ Muhammadiyah Sidoarjo, Jalan Majapahit 666B, Sidoarjo, Indonesia
}

fitrianh@umsida.ac.id*; cindytaurusta@umsida.ac.id; rahmania.sriuntari@umsida.ac.id; dininurul00@gmail.com; rindiani218@gmail.com

*Penulis Koresponden

\begin{tabular}{|c|}
\hline ABSTRAK \\
\hline $\begin{array}{l}\text { Inovasi media pembelajaran berbasis teknologi informasi saat ini sangat dibutuhkan sebagai } \\
\text { alternatif pembelajaran di masa pandemi covid 19. Salah satu inovasi media berbasis teknologi } \\
\text { inovasi yaitu gim edukasi berbasis android. Tujuan dari penelitian ini yaitu mengembangkan gim } \\
\text { edukasi berbasis android pada mata kuliah Pemrograman Berorientasi Objek (PBO) pada } \\
\text { mahasiswa Pendidikan Teknologi Informasi (PTI) serta mengetahui kelayakannya sebagai } \\
\text { optimasi pembelajaran daring. Penelitian Research and Development (R\&D) ini menggunakan } \\
\text { model pengembangan ADDIE (Analysis, Design, Develop, Implement, Evaluate). Subjek } \\
\text { penelitian yaitu mahasiswa PTI semester lima. Instrumen penelitian yang digunakan yaitu angket. } \\
\text { Gim edukasi divalidasi oleh ahli materi, ahli media pembelajaran, serta diuji coba pada kelompok } \\
\text { terbatas. Tingkat kelayakan gim edukasi berbasis android oleh ahli materi pada aspek isi materi } \\
\text { sebesar 93,2\% dan aspek bahasa sebesar 93,3\% dengan kriteria sangat layak. Tingkat kelayakan } \\
\text { oleh ahli media yaitu } 90 \% \text { untuk aspek kualitas isi, aspek desain dan audio dengan persentase } \\
\text { 95\%, dan 93,75 \% pada aspek interaksi dan umpan balik dengan kriteria sangat layak. Hasil uji } \\
\text { coba kelompok terbatas mencapai persentase } 96 \% \text { dengan kriteria sangat layak. Berdasarkan uji } \\
\text { kelayakan yang telah dilakukan dapat disimpulkan gim edukasi berbasis android layak dan dapat } \\
\text { diimplementasikan pada proses pembelajaran. } \\
\text { Kata Kunci: Gim Edukasi; Inovasi Media; Pandemi Covid 19; Pembelajaran Daring }\end{array}$ \\
\hline ABSTRACT \\
\hline $\begin{array}{l}\text { The innovation in Information and Communication Technology (ICT)-based learning media is a } \\
\text { critical learning alternative during the Covid-19 pandemic. One of the ICT-based learning media } \\
\text { is android-based educational games. This research aims to develop android-based educational } \\
\text { games on object-oriented programming (OOP) courses for Information Technology Education } \\
\text { (ITE) students and to find out the feasibility of this product in online learning optimization. This } \\
\text { research employed Research and Development (R\&D) with Analysis, Design, Develop, } \\
\text { Implement, Evaluate (ADDIE) development model. Participants of this research were the fifth- } \\
\text { semester ITE students. Questionnaires validated by learning material and media experts were } \\
\text { tested on limited groups before being distributed to the participants. Results show that the } \\
\text { feasibility level on the material content aspect is } 93.2 \% \text {, and the language aspect is } 93.3 \% \text {, }\end{array}$ \\
\hline
\end{tabular}


referring to very feasible criteria. The feasibility level on the content quality is $90 \%$, the design and audio aspects are $95 \%$, and interaction and feedback are $93.75 \%$, referring to very feasible criteria. The trial results of the limited group are $96 \%$ with very feasible criteria. These findings indicate that android-based educational games are feasible and can be implemented in the learning process.

Keywords: Educational Games, Media Innovation, Covid-19 Pandemic, Online Learning

diunggah: 2021-01-12, direvisi: 2021-03-29, diterima: 2021-04-01,dipublikasi: 2021-05-22

Copyright (c) 2021 Hasanah et al

This is an open access article under the CC-BY license

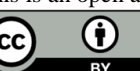

Cara sitasi: Hasanah, F. N. ., Taurusta, C., Sri Untari, R., Nurul Hidayah, D., \& Rindiani, R. (2021). Gim edukasi berbasis android sebagai optimasi pembelajaran daring di masa pandemi Covid 19. JINoP (Jurnal Inovasi Pembelajaran), 7(1), 55-67. https://doi.org/10.22219/jinop.v7i1.15176

\section{PENDAHULUAN}

Dunia internasional digemparkan dengan maraknya wabah virus corona (covid-19) sejak penghujung akhir tahun 2019, termasuk di Indonesia. Wabah virus ini telah membuat kepanikan dan memakan banyak korban jiwa. Seperti dilakukan oleh banyak negara, untuk mencegah penularan virus corona di sekolah, Menteri Pendidikan dan Kebudayaan menerbitkan surat edaran bertanggal 24 Maret 2020 yang mengatur pelaksanaan pendidikan pada masa darurat penyebaran virus corona melalui kebijakan "Belajar dari Rumah" yang dirasa tepat untuk mencegah penyebaran covid-19 di lingkungan pendidikan (Surat Edaran Menteri No.4 Tahun 2020, 2020). Dalam surat edaran tersebut dijelaskan bahwa proses belajar dilaksanakan di rumah melalui pembelajaran daring atau jarak jauh dengan penekanan pada pengalaman belajar yang bermakna bagi siswa.

Dengan adanya surat edaran tersebut setiap institusi pendidikan dituntut mampu melakukan pembelajaran jarak jauh agar dapat memutus rantai penyebaran virus (Firdaus \& Untari, 2020). Selain pembelajaran jarak jauh, institusi pendidikan juga dituntut untuk mempersiapkan orientasi dan literasi baru dalam pendidikan. Pendidik harus membangun kemampuan literasi mahasiswa, baik literasi lama (membaca, menulis, dan berhitung), dan literasi baru (literasi data, teknologi, dan humanisme) (Hamidulloh, 2018). Literasi data atau digital ditujukan pada peningkatan kemampuan membaca, menganalisis, dan menggunakan informasi di dunia digital (big data), keterampilan dalam pemanfaatan teknologi bertujuan untuk memberikan pemahaman tentang cara kerja aplikasi mesin dan teknologi, dan literasi manusia diarahkan pada peningkatan keterampilan komunikasi dan penguasaan ilmu desain (Yahya, 2018). Dengan literasi data, teknologi, dan humanisme atau sumber daya manusia diharapkan pendidik dapat mendidik dan meningkatkan kualitas lulusan yang kreatif, inovatif, dan kompetitif agar mampu mengikuti perkembangan zaman yang lebih maju. Hal tersebut dapat dicapai dengan cara memanfaatkan teknologi sebagai alat bantu dalam kegiatan belajar.

Kegiatan belajar memerlukan sumber belajar untuk memperlancar tercapainya tujuan belajar. Sumber belajar adalah segala sumber daya (resources) yang meliputi materi pelajaran, manusia, alat, teknik, dan lingkungan yang dapat digunakan untuk mendukung pencapaian tujuan pembelajaran (Musfiqon, 2012). Sumber belajar dapat berupa pesan, manusia, bahan, alat, metode, dan lingkungan (Abdulhak \& Darmawan, 2013). Bahan meliputi program, media atau software yang mengandung pesan untuk disajikan. Sebagaimana yang terjadi saat 
pandemi, banyak perubahan pada berbagai aspek kehidupan ketika teknologi memiliki peranan yang sangat besar dan menjadi motor utama perubahan di setiap aspek kehidupan.

Teknologi yang berkembang saat ini sudah memasuki tahap digital, termasuk di Indonesia. Setiap bidang sudah mulai memanfaatkan teknologi untuk memudahkan pekerjaan (Lestari, 2018). Perkembangan teknologi informasi membawa perubahan yang banyak terhadap pendidikan sekarang ini. Hal ini juga sesuai dengan pendapat Neil (2011) yang menyatakan bahwa teknologi digital kini sudah mulai digunakan di dalam lembaga pendidikan sebagai sarana untuk mendukung pembelajaran, baik sebagai alat informasi (sebagai sarana mengakses informasi) atau sebagai alat pembelajaran (sebagai sarana penunjang kegiatan belajar dan tugas). Pembelajaran ada dalam komponen metode mengajar sebagai salah satu upaya untuk meningkatkan interaksi guru dengan siswa dan interaksi siswa dengan lingkungan belajarnya (Sudjana \& Rivai, 2011). Salah satu fungsi utama media pembelajaran adalah sebagai alat perantara atau fasilitator dalam kegiatan pembelajaran.

Media pembelajaran dapat membantu siswa meningkatkan pemahaman, penyajian data dengan menarik dan terpercaya, memudahkan penafsiran data, dan memadatkan informasi (Arsyad, 2011). Inovasi media pembelajaran berbasis teknologi informasi saat ini sangat dibutuhkan sebagai alternatif pembelajaran di masa pandemi covid-19. Salah satu inovasi media berbasis teknologi inovasi, yaitu gim edukasi berbasis android. Salah satu perangkat teknologi yang sedang populer saat ini yang mudah dibawa kemana-mana dan dapat digunakan sewaktu-waktu adalah platform mobile berbasis android (Ariyani \& Sumbawati, 2018). Android adalah sistem operasi yang berjalan untuk platform mobile berbasis linux yang populer dan dikembangkan oleh Google Inc. Android merupakan sistem operasi open source, artinya gratis dan bebas untuk dikembangkan oleh para pengembang aplikasi (Haryono \& Alhafidzs, 2018). Android berjalan pada perangkat ponsel pintar atau smart phone dengan penggunanya yang sangat banyak, baik muda maupun yang tua, khususnya di kalangan pelajar. Gawai berfungsi untuk mengkses berbagai macam informasi, materi mata pelajaran, ataupun hiburan.

Gim edukasi dapat membantu peserta didik dalam mendapatkan dan menyampaikan konten pembelajaran dengan mudah, menarik, dan menghibur. Dengan hal tersebut diharapakan tercapainya hasil belajar siswa yang lebih optimal. Sesuai dengan penelitian Taurusta bahwa gim digolongkan menjadi beberapa genre, di antaranya RPG (Role Playing Game), adventure, sport, fight, RTS (Real Time Strategy) shooter, racing, dan beberapa genre lainnya (Taurusta \& Findawati, 2017). Barros menyampaikan gim adalah permainan menggunakan media elektronik sebagai hiburan berbentuk multimedia yang dibuat semenarik mungkin agar pemain bisa mendapatkan sesuatu sehingga adanya kepuasaan batin (Barros et al., 2018).

Gim dianggap berhasil dalam meningkatkan logika dan pemahaman pemain. Dampaknya antara lain anak dapat belajar mengambil keputusan, menentukan, mencipta, membongkar, memasangkan, mencoba, mengembalikan, mengeluarkan pendapat dan memecahkan masalah, mengerjakan sesuatu secara tuntas, bekerja sama dengan teman, dan mengalami berbagai macam perasaan (Safitri, 2015). Hal tersebut sejalan dengan penelitian Chandra (2017), bahwa respon mahasiswa terhadap penggunaan gim edukasi sebagai media pembelajaran mata kuliah praktik teknik digital mendapatkan rerata skor 73\% dengan kategori "layak" untuk 
digunakan sebagai media pembelajaran. Gim edukasi menuntut pemain untuk menyelesaikan permasalahan yang ada (Hockenbury \& Hockenbury, 2011). Permainan didesain untuk mensimulasikan permasalahan yang ada sehingga pemain secara tidak langsung terdorong untuk memperoleh esensi dan ilmu yang dapat digunakan untuk menyelesaikan permasalahan dalam pembelajaran. Sesuai dengan penelitian yang dilakukan oleh Risnawati et al., (2018), bahwa gim edukasi yang dikembangkan dengan Adobe Flash Professional CC 2015 sangat valid dengan validitas $84,1 \%$, sangat praktis dengan kepraktisan $85,42 \%$, dan efektif dengan efektivitas $80 \%$ untuk memfasilitasi kemampuan pemecahan masalah matematis siswa. Selain itu penerapan gim edukasi pada mata kuliah Sistem Operasi untuk mahasiswa Prodi Pendidikan Teknik Informatika dan Komputer Universitas Bung Hatta diperoleh hasil sangat baik karena telah memenuhi kriteria sangat baik dengan nilai rata-rata 91,38\% (Zulfiandra et al., 2021).

Pendidikan Teknologi Informasi (PTI) merupakan salah satu Program Studi di Fakultas Psikologi dan Ilmu Pendidikan (FPIP) Universitas Muhammadiyah Sidoarjo (UMSIDA) yang mempunyai visi menjadi Prodi PTI yang unggul dan inovatif dalam pengembangan IPTEKS berdasarkan nilai-nilai Islam untuk kesejahteraan. Keunggulan Prodi PTI adalah pengembang inovasi media pembelajaran berbasis teknologi informasi. Di masa pandemi saat ini pembelajaran di PTI UMSIDA dilakukan secara daring dengan memanfaatkan e-learning berbasis moodle. Pada e-learning tersebut terdapat beberapa objek yang dapat dimanfaatkan oleh dosen di antaranya yaitu teks, video, dan audio. Berdasarkan analisis awal yang dilakukan pada saat perkuliahan Pemrograman Berorientasi Objek (PBO) diperoleh bahwa mahasiswa PTI kurang termotivasi dikarenakan pembelajaran daring menggunakan media yang kurang bervariasi, yaitu video pembelajaran dan power point. Berdasarkan paparan latar belakang tersebut, peneliti mengembangkan media pembelajaran, yaitu gim edukasi berbasis android pada mata kuliah PBO. Tujuan penelitian ini yaitu mengembangkan gim edukasi berbasis android pada mata kuliah PBO mahasiswa PTI dan mengetahui kelayakam gim edukasi berbasis android pada mata kuliah PBO mahasiswa PTI.

\section{METODE}

Pengembangan media ini menggunakan jenis penelitian dan pengembangan (Research and Development). Hasil dari pengembangan produk dalam penelitian ini berupa media pembelajaran gim edukasi berbasis android. Model pengembangan yang digunakan di dalam penelitian ini yaitu model ADDIE yang dikembangkan William Lee. Model pengembangan ADDIE terdiri dari beberapa tahapan, yaitu analysis, design, develop, implement, dan evaluate (Molenda, 2015). Harapannya setelah dilakukan analisa maka produk media berupa gim edukasi yang dikembangakan layak diterapkan untuk subjek penelitian. Prosedur pengembangan media pembelajaran berupa gim edukasi berbasis android dijabarkan melalui flowchart yang ditunjukkan pada Gambar 1. 


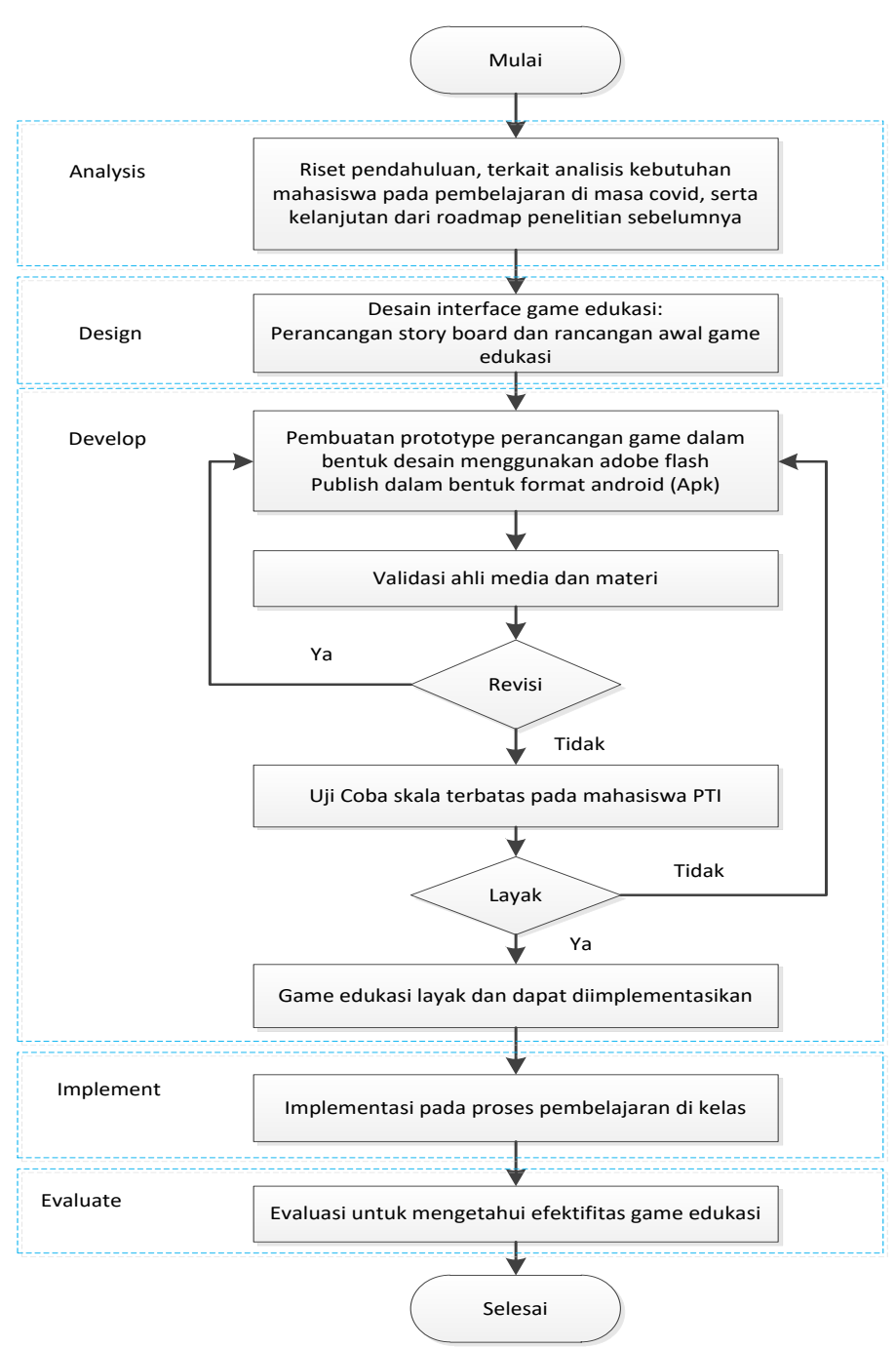

\section{Gambar 1. Prosedur Pengembangan Game Edukasi}

Tahap analysis (analisis) merupakan proses mendefinisikan apa yang akan dipelajari oleh mahasiswa, yaitu melakukan analisis kebutuhan (needs assessment), mengidentifikasi masalah (kebutuhan), dan melakukan analisis tugas (task analysis). Pada tahap ini terbagi menjadi tiga segmen, yaitu analisis pebelajar, analisis pembelajaran (tujuan pembelajaran), dan analisis media pengiriman daring. Kegiatan pada tahap analisis yang akan dilakukan adalah menganalisis karakteristik mahasiswa, menganalisis kebutuhan pembelajaran, pembuatan flowchart proses pengembangan produk, dan menentukan jenis media yang dikembangkan. Analisis kebutuhan didapatkan dari hasil penelitian yang dilakukan sebelumnya sesuai dengan roadmap penelitian.

Tahap design (desain) yaitu tahapan yang dilakukan untuk pembuatan rancangan produk (blue print), meliputi desain rancangan media berupa gim edukasi, spesifikasi media, konten media, perancangan storyboard yang meliputi rencana desain template atau user interface dan juga materi. Storyboard digunakan sebagai gambaran atau pedoman pembuatan gim yang akan dikembangkan yang kemudian memasuki tahap pembuatan tampilan atau yang disebut dengan desain antarmuka. 
Tahap develop (pengembangan) merupakan implementasi dari blue print yang telah dibuat. Pada tahap ini dikembangakan media pembelajaran berupa gim edukasi berbasis android dan pengujian produk yang telah dikembangkan. Desain antarmuka dan objek yang ada di dalam gim dirancang menggunakan piranti lunak Adobe Illustrator CC 2019 dan piranti lunak pendukungnya Affinity Designer. Kemudian semua akan diolah menggunakan Game Enggine Unity 2018 dengan Bahasa Pemrograman C\#. Aplikasi SDK, JDK, dan NDK ditambahkan agar aplikasi dapat dijalankan di sistem operasi Android. Setelah produk selesai dikembangkan, media pembelajaran berupa gim edukasi, dilakukan validasi oleh tim ahli media dan ahli materi untuk memastikan kualitas media yang akan diterapkan pada proses pembelajaran. Jika media telah dinyatakan valid maka media siap untuk dilakukan uji coba skala terbatas pada mahasiswa semester 5 yang telah mengampu mata kuliah PBO untuk mendapatkan masukan terkait media.

Tahap implement (implementasi) yaitu tahapan untuk menerapkan media gim edukasi yang telah dinyatakan layak oleh ahli media dan ahli materi dan sudah dilakukan ujicoba skala terbatas, yaitu penerapan media pada proses pembelajaran mata kuliah PBO. Tahap evaluate (evaluasi) merupakan tahap untuk melakukan evaluasi dari hasil tahap implementasi. Dari tahap evaluasi ini akan diketahui efektivitas dari penggunaan media gim edukasi yang telah dikembangkan. Subjek uji coba skala terbatas dilakukan pada mahasiswa semester 5 yang telah menempuh mata kuliah PBO, yaitu sebanyak 10 mahasiswa. Objek yang diteliti adalah pengembangan media pembelajaran berupa gim edukasi berbasis android pada mata kuliah PBO. Instrumen yang digunakan berupa angket untuk mengetahui kelayakan media dari ahli media dan materi. Instrumen ahli media dengan kriteria aspek penulisan kualitas isi, desain dan audio, interaksi, dan umpan balik. Instrumen ahli materi meliputi isi materi dan bahasa. Instrumen uji kelayakan media oleh pengguna, yaitu mahasiswa didasarkan pada aspek tampilan, penyajian materi, dan kebermanfaatan. Instrumen yang telah disusun kemudian divalidasi oleh ahli. Pada penelitian ini dilakukan validasi ahli materi dan validasi ahli media. Media yang telah dinyatakan layak oleh ahli materi dan media maka diujicobakan pada mahasiswa.

Teknik analisis data untuk kriteria valid dan layak dengan rumus (Arikunto, 2013) :

$P=\frac{\sum X}{N} \times 100 \%$

Keterangan:

$P \quad:$ persentase skor

$\sum X$ : jumlah skor

$N$ : skor maksimal

Instrumen yang digunakan adalah angket untuk mengetahui tingkat kelayakan media. Penentuan tingkat kelayakan media pembelajaran digunakan kriteria penilaian ditunjukkan pada Tabel 1. (Akbar, 2013).

Tabel 1. Kriteria Kelayakan

\begin{tabular}{ccc}
\hline Persent $(\%)$ & Tingkat Kelayakan & Keterangan \\
\hline $81-100$ & Sangat layak & Dapat digunakan tanpa revisi \\
$61-80$ & Layak & Dapat digunakan revisi kecil \\
$41-60$ & Cukup layak & Dapat digunakan dengan besar \\
$21-40$ & Kurang layak & Tidak dapat digunakan \\
$0-20$ & Tidak layak & Tidak dapat digunakan \\
\hline
\end{tabular}




\section{HASIL DAN PEMBAHASAN}

Hasil pengembangan gim edukasi berbasis android berbentuk file dengan ekstensi "apk" dan diinstal pada smartphone. Pengembangan gim edukasi ini meliputi beberapa tahap sesuai dengan model pengembangan ADDIE (Analysis, Design, Develop, Implement, dan Evaluate). Pada tahap analysis dilakukan analisis kebutuhan pengguna dan analisis kebutuhan pengembangan gim edukasi dari sisi hardware dan software. Pada analisis kebutuhan pengguna dilakukan identifikasi masalah untuk menentukan solusi yang dibutuhkan. Identifikasi masalah dilakukan pada saat perkuliahan mata kuliah PBO dan berdasarkan hasil observasi diperoleh bahwa mahasiswa PTI kurang termotivasi dikarenakan pembelajaran daring menggunakan media yang kurang bervariasi, yaitu video pembelajaran dan Power Point. Pada pembelajaran daring saat ini dibutuhkan media berbasis teknologi yang efektif dan efisien untuk menunjang pembelajaran, sehingga dikembangkan gim edukasi dengan spesifikasi kebutuhan, yaitu perangkat keras, meliputi laptop, RAM $8 \mathrm{~Gb}$, CPU intel core i7. Software yang digunakan dalam pengembangan gim edukasi adalah sistem operasi Windows 1064 bit, Unity 3D 2018, Visual Studio Code untuk menulis coding program, Adobe Illustrator 2018 untuk merancang tampilan antarmuka pengguna dari gim edukasi, dan Affinity Desainer digunakan untuk pendukung pembuatan desain.

Tahap design merupakan tahapan dalam merancang dan membuat desain awal. Pada tahap ini peneliti melakukan rancangan alur cerita, desain antarmuka pengguna, desain map, dan tokoh dalam gim. Alur cerita yang dibuat pada gime edukasi ini yaitu bercerita tentang Jojo, mahasiswa semester 5, yang akan menyelesaikan misi dari dosen mata kuliah PBO yang terdiri dari 3 pos, yaitu teori, praktikum, dan evaluasi. Sebelum konten pada gim edukasi ini dikembangkan, terlebih dahulu peneliti merancang story board pada gim edukasi. Dalam pembuatan gim, genre gim harus di tentukan terlebih dahulu sebagaimana hasil penelitian Kholisho \& Marfuatun (2019), bahwa ketepatan pemilihan genre gim dengan konten dan metode pembelajaran sangat membantu dalam meningkatkan efektifitas penyampaian pembelajaran. Storyboard ini digunakan oleh peneliti sebagai acuan dalam pengembangan tampilan antarmuka pengguna pada gim edukasi. Storyboard pembuatan gim edukasi dapat dilihat pada Gambar 2.
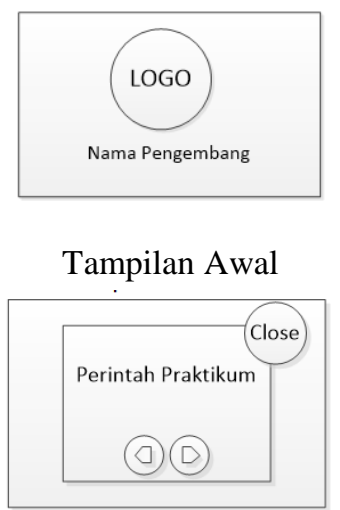

Scene Praktikum
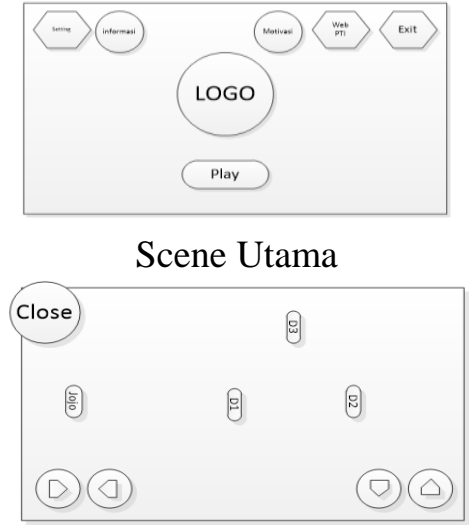

Scene Gim

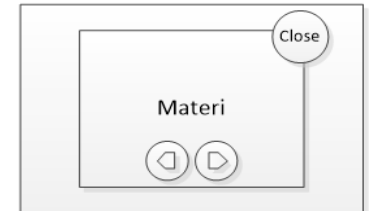

Scene Materi

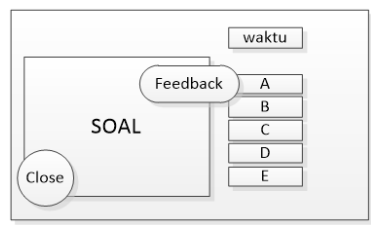

Scene Evaluasi

Gambar 2. Storyboard Gim Edukasi 
Desain antarmuka pengguna latar pada gim edukasi ini sebelum diolah pada gim engine ditunjukkan pada Gambar 3.

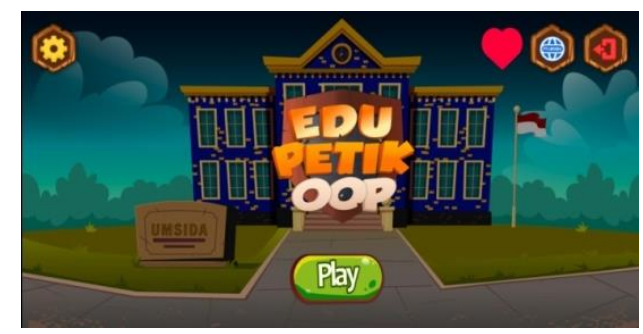

\section{Gambar 3. Halaman Utama Game Edukasi}

Tahap develop merupakan tahap pembuatan produksi atau pengembangan gim edukasi. Jenis gim edukasi yang digunakan pada penelitian ini, yaitu jenis Role Playing Game (RPG). Gim berjenis RPG memiliki banyak variasi dan dinamika permainan yang dapat digunakan sebagai mekanisme untuk meningkatkan efektivitas pembelajaran. Skenario dengan menjadikan pemain sebagai tokoh utama dapat membantu penyampaian materi yang diajarkan di dalam permainan (Hermawan et al., 2017). Pengembangan gim dibuat sesuai dengan storyboard, dimulai dari pembuatan desain antarmuka pengguna, karakter dalam bentuk grafik, dan dikombinasikan dengan perangkat lunak game engine dengan pemberian fungsi dengan kode program. Pembuatan desain antarmuka pengguna menggunakan perangkat lunak desain grafis, yaitu Adobe Ilustrator CC 2019 dan Affinity Designer. Gambaran tampilan antarmuka pengguna perjalanan Jojo menuju karakter Dosen ditunjukkan pada Gambar 4.

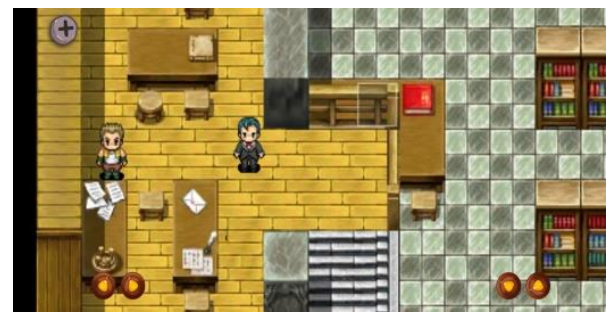

Scene Awal Gim Edukasi

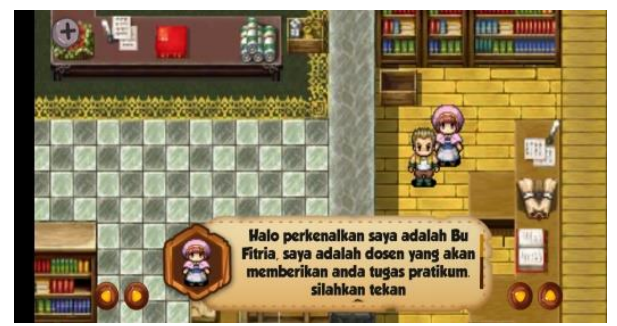

Scene Karakter Jojo Menerima Misi

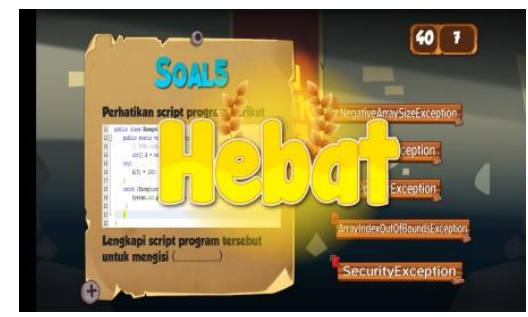

Scene Evaluasi

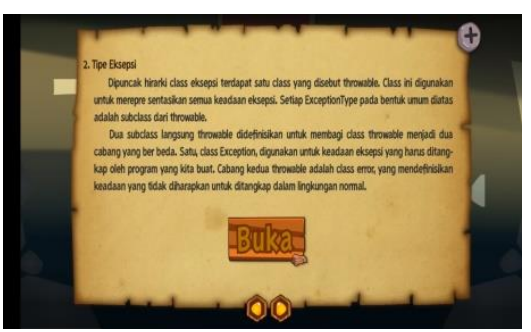

Scene Materi

\section{Gambar 4. Tampilan Antarmuka Pengguna Gim Edukasi}

Misi dimulai dari pembacaan materi yang dijaga oleh karakter 1, yaitu Pak Akbar. Setelah menerima perintah dari karakter 1, Jojo harus menyelesaikan misi pertama menuju ke karakter ke 2 yaitu karakter Bu Cindy. Bu Cindy akan 
memberikan misi, yaitu menyelesaikan materi yang disampaikan sehingga dapat melanjutkan ke misi selanjutnya. Misi ke dua yaitu praktikum yang dijaga oleh karakter 3 Bu Fitria, Jojo harus menyelesaikan misi praktikum sesuai dengan arahan untuk dapat melanjutkan misi selanjutnya. Misi terakhir yaitu evaluasi yang dijaga oleh karakter $3 \mathrm{Bu}$ Rahmania. Pada misi terakhir ini Jojo harus menyelesaikan pertanyaan yang diberikan dengan durasi waktu 30 detik per pertanyaan. Desain antarmuka pengguna dibuat untuk mempermudah penggunaan gim edukasi.

Selain proses produksi gim dengan perangkat lunak, pada tahap develop dilakukan evaluasi dan revisi. Thiagarajan membagi tahapan pengembangan menjadi dua, yaitu expert appraisal dan developmental testing (Nasrudin et al., 2018). Pada tahap expert appraisal dilakukan validasi atau menilai kelayakan rancangan produk. Validasi dilakukan oleh ahli dalam bidangnya, yaitu validasi ahli materi dan ahli media. Hasil validasi ahli materi maupun ahli media ditunjukkan pada Tabel 2.

Tabel 2 Hasil Validasi Ahli

\begin{tabular}{llc}
\hline \multicolumn{1}{c}{ Validator } & \multicolumn{1}{c}{ Indikator } & Persentase (\%) \\
\hline Ahli Materi & Isi materi & 93,2 \\
\hline & Bahasa & 93,3 \\
\hline Ahli Media & Kualitas Isi & 90 \\
\hline & Desain dan Audio & 95 \\
\hline & Interaksi dan Umpan Balik & 93,75 \\
\hline
\end{tabular}

Berdasarkan Tabel 2 diperoleh persentase ahli materi yang meliputi indikator isi materi 93,2 \% dan bahasa 93,3\% dengan kriteria sangat tinggi. Persentase ahli media dengan indikator kualitas isi, yaitu $90 \%$, desain dan audio 95\%, serta interaksi dan umpan balik 93,75\% dengan kriteria sangat tinggi, sehingga dapat disimpulkan gim edukasi dinyatakan layak dan dilanjutkan untuk tahap uji coba skala terbatas. Pendapat dan saran pada penilaian yang diperoleh digunakan sebagai revisi untuk memperbaiki prototipe gie edukasi yang telah dibuat. Revisi yang dilakukan sesuai masukan dari validator ahli materi dan media ditunjukkan pada Tabel 3.

Tabel 3 Revisi Gim Edukasi

\begin{tabular}{l|l}
\multicolumn{1}{c}{$\begin{array}{c}\text { Poin yang } \\
\text { direvisi }\end{array}$} \\
$\begin{array}{l}\text { Memberi tanda } \\
\text { Jojuk petunjuk } \\
\text { karakter dosen }\end{array}$ \\
$\begin{array}{l}\text { Memperjelas } \\
\text { petunjuk pada } \\
\text { praktikum }\end{array}$
\end{tabular}


Tahap selanjutnya uji coba gim edukasi pada subjek, yaitu mahasiwa PTI semester 5 sejumlah 10 mahasiswa. Melalui kegiatan ini didapatkan komentar responden, yaitu mahasiswa dari subjek penelitian, untuk kemudian dilakukan revisi pada gim edukasi. Berdasarkan hasil uji coba diperoleh kesimpulan bahwa dari aspek tampilan media, aspek materi, dan aspek kebermanfaatan media diperoleh rata-rata $96 \%$ dengan kriteria kelayakan sangat tinggi sehingga dapat disimpulkan media gim edukasi dapat digunakan untuk pembelajaran. Sesuai dengan penelitian gim edukasi oleh Moreno-Ger et al. (2008) bahwa penggunaan permainan edukatif di lingkungan belajar merupakan tren yang semakin relevan. Sifat motivasi dan imersif dari pembelajaran berbasis permainan telah dipelajari secara mendalam dalam literatur. Hasil penelitian ini juga didukung oleh Firmandasari et al. (2020) yang menyatakan bahwa gim edukasi berbasis android dapat membantu proses pembelajaran pada anak menjadi lebih menyenangkan dan tidak mudah jenuh.

Pemakaian media pembelajaran dalam proses belajar mengajar dapat membangkitkan minat dan keinginan yang baru, membangkitkan motivasi dan rangsangan kegiatan belajar, bahkan membawa pengaruh-pengaruh psikologis terhadap siswa (Riyanti \& Rusdi, 2018). Selain itu, penggunaan gim edukasi dalam proses belajar mengajar memudahkan mahasiswa dalam memahami materi pembelajaran. Kemampuan yang dimiliki oleh mahasiswa tersebut merupakan bagian dari literasi digital, yang dapat diartikan sebagai kemampuan penggunaan dan pengelolaan sistem teknologi, informasi, dan komunikasi (Irhandayaningsih, 2020). Lebih lanjut, Hague \& Payton (2010) menjelaskan literasi digital sebagai kemampuan individu untuk menerapkan keterampilan fungsional pada perangkat digital sehingga mahasiswa dapat menemukan dan memilih informasi, berpikir kritis, berkreativitas, berkolaborasi bersama orang lain, berkomunikasi secara efektif, dan tetap menghiraukan keamanan elektronik serta konteks sosial-budaya yang berkembang. Literasi sangat relevan dengan era ketika hidup manusia banyak dikuasai oleh teknologi informasi, yaitu literasi digital (Sumiati, 2020).

Alfin menyatakan dengan mengoptimalkan penggunaan teknologi sebagai media pembelajaran dapat membentuk generasi kreatif, inovatif, serta kompetitif (Alfin, 2018). Pada masa pandemi covid-19 literasi digital dibutuhkan untuk dapat berpartisipasi di dunia modern dan mengantisipasi penyebaran informasi negatif (Sutrisna, 2020). Dengan menerapkan gim edukasi dalam pembelajaran mahasiswa dilatih untuk komunikatif memahami kinerja jejaring dan komunikasi di dunia digital melalui setiap petunjuk atau perintah yang telah dicantumkan pada konten di gim edukasi. Penerapan gaim edukasi akan menciptakan pola pikir kreatif dengan melakukan hal baru dengan cara yang baru dan kritis dalam menyikapi konten yang ada pada media pembelajaran dalam menghadapi pembelajaran di masa pandemi covid-19. Sesuai dengan penelitian Rasyid et al. (2020), bahwa dengan menerapkan aplikasi mobile learning berbasis RPG maker MV dapat meningkatkan kemampuan berpikir kritis.

\section{SIMPULAN}

Berdasarkan hasil penelitian dapat disimpulkan bahwa gim edukasi berbasis android yang dikembangkan dengan model pengembangan ADDIE menunjukkan gim layak digunakan dalam pembelajaran. Gim edukasi telah divalidasi oleh ahli materi dan ahli media dengan persentase ahli materi yang meliputi indikator isi 
materi 93,2\% dan bahasa 93,3\% dengan kriteria sangat tinggi. Persentase ahli media dengan indikator kualitas isi, yaitu 90\%, desain dan audio 95\%, serta interaksi dan umpan balik $93,75 \%$ dengan kriteria sangat tinggi. Hasil uji coba skala terbatas dari aspek tampilan media, aspek materi, dan aspek kebermanfaatan media diperoleh rata-rata 96\% dengan kriteria kelayakan sangat tinggi sehingga dapat disimpulkan media game edukasi dapat digunakan untuk pembelajaran. Berdasarkan hasil penelitian yang diperoleh, maka saran yang dapat peneliti berikan berdasarkan hasil penelitian yaitu gim edukasi dapat digunakan sebagai inovasi pembelajaran daring di masa pandemi covid, sehingga dapat dikembangkan untuk mata kuliah yang lainnya.

\section{DAFTAR PUSTAKA}

Abdulhak, I., \& Darmawan, D. (2013). Teknologi Pendidikan. PT Remaja Rosdakarya Offset.

Akbar, S. (2013). Instrumen Perangkat Pembelajaran. PT Remaja Rosdakarya.

Alfin, J. (2018). Membangun Budaya Literasi dalam Pembelajaran Bahasa Indonesia Menghadapai Era Revolusi Industri 4.0. PENTAS: Jurnal Ilmiah Pendidikan Bahasa Dan Sastra Indonesia, 4(2), 60-66. https://jurnal.univpgri-palembang.ac.id/index.php/Prosidingpps/article/view/ 2511

Arikunto, S. (2013). Prosedur Penelitian Suatu Pendekatan Praktik. PT Rineka Cipta.

Ariyani, R. T., \& Sumbawati, M. S. (2018). Pengembangan Game "TeKaJe" Sebagai Media Pembelajaran Interaktif Pada Mata Pelajaran Komputer Dan Jaringan Dasar Di SMK Negeri 3 Buduran Sidoarjo. Jurnal IT-Edu, 03(01), 190-199.

Arsyad, A. (2011). Media Pembelajaran. PT Raja Grafindo Persada.

Barros, B., Marisa, F., \& Wijaya, I. D. (2018). Pembuatan Game Kuis Siapa Pintar. J I M P - Jurnal Informatika Merdeka Pasuruan, 3(1), 44-52. https://doi.org/ 10.37438/jimp.v3i1.88

Chandra, A. (2017). Rancang Bangun Game Edukasi Sebagai Media Pembelajaran Mata Kuliah Praktik Teknik Digital. Jurnal Edukasi Elektro, 1(1), 92-98. https://doi.org/10.21831/jee.v1i1.15121

Firdaus, A. F., \& Untari, R. S. (2020). Android-Based Digital Book Development for Basic Network Students in Smk Dian Indonesia. JICTE (Journal of Information and Computer Technology Education), 4(2), 7-14. https://doi.org/ 10.21070/jicte.v4i2.921

Firmandasari, R. A., Suryawinata, M., Hasanah, F. N., \& Untari, R. S. (2020). Game bahasa jawa krama sebagai media pembelajaran anak berbasis android. Jurnal Ilmiah Penelitian Dan Pembelajaran Informatika, 05(02), 150-160.

Hague, C., \& Payton, S. (2010). Digital Literacy Across the Curriculum. Futurelab. https://www.nfer.ac.uk/publications/futl06/futl06.pdf

Hamidulloh, I. (2018). Penguatan Literasi Baru Pada Guru Madrasah Ibtidaiyah dalam Menjawab Tantangan Era Revolusi Industri 4.0. Jurnal Of Research and Thought of Islamic Education, 1(1), 1-21.

Haryono, A., \& Alhafidzs, M. R. . (2018). Pengembangan Mobile Learning Berbasis Android Sebagai Media Pembelajaran Ekonomi. Jurnal Pendidikan Ekonomi, 11(2), 118-124.

Hermawan, D. P., Herumurti, D., \& Kuswardayan, I. (2017). Efektivitas 
Penggunaan Game Edukasi Berjenis Puzzle, RPG dan Puzzle RPG Sebagai Sarana Belajar Matematika. JUTI: Jurnal Ilmiah Teknologi Informasi, 15(2), 195. https://doi.org/10.12962/j24068535.v15i2.a663

Hockenbury, D. H., \& Hockenbury, S. E. (2011). Discovering Psychology Fifth Edition.

Irhandayaningsih, A. (2020). Pengukuran literasi digital pada peserta pembelajaran daring di masa pandemi covid-19. Anuva, 4(2), 231-240.

Surat Edaran Menteri No.4 Tahun 2020, 300 (2020).

Kholisho, Y. N., \& Marfuatun. (2019). Efektifitas Penggunaan Game Analisis Training terhadap Peningkatan Kemampuan Berfikir Induktif Remaja. EDUMATIC : Jurnal Pendidikan Informatika, 3(2), 99-108. https://doi.org/ 10.29408/edumatic.v4i2.2683

Lestari, S. (2018). Peran Teknologi dalam Pendidikan di Era Globalisasi. Edureligia; Jurnal Pendidikan Agama Islam, 2(2), 94-100. https://doi.org/ 10.33650/edureligia.v2i2.459

Molenda, M. (2015). In search of the elusive ADDIE Model. Performance Improvement, 54(2), 40-42. https://doi.org/10.1002/pfi

Moreno-Ger, P., Burgos, D., Martínez-Ortiz, I., Sierra, J. L., \& Fernández-Manjón, B. (2008). Educational game design for online education. Computers in Human Behavior, 24(6), 2530-2540. https://doi.org/10.1016/j.chb.2008. 03.012

Musfiqon. (2012). Pengembangan Media dan Sumber Pembelajaran. Prestasi Pustaka Publisher.

Nasrudin, N., Agustina, I., \& Akrim, A. (2018). Multimedia Educational Game Approach for Psychological Conditional. International Journal Engineering Technology, 7(2.9), 78-81.

Neil, S. (2011). Education and Technology Key Issues and Debates. Replika Press Pvt Ltd.

Rasyid, A., Gaffar, A. A., \& Utari, W. (2020). Efektofotas Aplikasi Mobile Learning Role Play Game (RPG) Maker MV untuk Meningkatkan Kemampuan Berfikir Kritis. Mangifera Edu, 4(2), 129-142.

Risnawati, Amir, Z., \& Wahyuningsih, D. (2018). The Development of Educational Game as Instructional Media to Facilitate Students' Capabilities in Mathematical Problem Solving. Journal of Physics: Conference Series, 1028(1). https://doi.org/10.1088/1742-6596/1028/1/012130

Riyanti, R., \& Rusdi, H. (2018). Efektifitas Penggunaan Game Edukasi Smartphone terhadap Hasil Belajar dan Motivasi Belajar Mahasiswa Pendidikan Biologi STKIP YAPIM Maros. Jurnal Ilmiah Pena, 1(2), 21-28.

Safitri, W. C. D. (2015). Pengembangan media board game untuk pembelajaran tematik di sekolah dasar. JINoP (Jurnal Inovasi Pembelajaran), 1(1), 181190. https://doi.org/10.22219/jinop.v1i1.2441

Sudjana, N., \& Rivai. (2011). Media Pengajaran. Sinar Baru Algesindo.

Sumiati, E. T. I. (2020). Manfaat Literasi Digital Bagi Masyarakat Dan Sektor Pendidikan Pada Saat Pandemi Covid-19. 3(2), 65-80.

Sutrisna, I. P. G. (2020). Gerakan Literasi Digital Pada Masa Pandemi Covid-19. Stilistika: Jurnal Pendidikan Bahasa Dan Seni, 8(2), 268-283. https://doi.org/10.5281/zenodo.3884420

Taurusta, C., \& Findawati, Y. (2017). Rancang Bangun Game Algoritma dan Struktur Data Berbasis Role Playing Game (RPG) Sebagai Media 
Pembelajaran Mahasiswa Teknik Informatika Universitas Muhammadiyah Sidoarjo. Jurnal Kinetik, 2(3), 175-188.

Yahya, M. (2018). Era Industri 4.0: Tantangan dan Peluang Perkembangan Pendidikan Kejuruan Indonesia.

Zulfiandra, T., Amelia, R., Khairi, A., Pendidikan, P., Informatika, T., Keguruan, F., \& Universitas, P. (2021). Pengembangan Game Edukasi Menggunakan Adobe Flash Pada Mata Informatika dan Komputer Universitas Bung Hatta. Jurnal Fakultas Keguruan Dan Ilmu Pendidikan, 11(01). 